\title{
Analysis of Banks Profitability: Domestic and Foreign Comparison
}

\author{
ABIOLA BABAJIDE ${ }^{1}$, FUNSO ABIODUN OKUNLOLA ${ }^{2}$, LAWAL ADEDOYIN ${ }^{3}$, TOCHUKWU \\ $\mathrm{OKAFOR}^{4}$, AREGHAN ISIBOR $^{5}$
}

\author{
$1,2,4, \& 5$ Department of Banking and Finance, Covenant University, Ota, Nigeria \\ ${ }^{3}$ Department of Banking and Finance, Landmark University, Nigeria
}

\begin{abstract}
Attempt at analyzing banks profitability informed this study. For sound and robust reviews of end report, the study took at comparing commercial banks across countries in Africa with emphasis on Nigeria, Ghana and South Africa owing to presumed position they occupy in the continent. To achieve its aims and from data provided by World Bank Group - International Monetary Funds, the study mirrored commercial banks profitability with total income (TI) hence, the dependent variable. The independent variables were proxied by total loan (TL) and customer deposits (CD). Data sets covers a ten (10) year period across cross -sections. Panel Autoregressive Distributed Lag (ARDL) regression of pooled ordinary least square, fixed effect model (FE) and random effect (REM) models, with Hausman Test of acceptance were specified. Similarly, Panel descriptive statistics and Panel Unit Rootstest were also tested and confirmed. Analysis was done with the aid of E-views statistical software v9. Results from the Panel ARDL finds Fixed Effect (FE) Model appropriate having taking into considerations the heterogeneity observations often not obseverded in the pooled ordinary least square and the randomnization effect in RE. By implication, findings indicate that total loan is statistically insignificant acorss sections showing a prob. 0.0714 with inverse correlation of 0.0169 while, customer deposit is statistically significant with a prob 0.000 and positive coefficient at 0.0480 as judged by the Hauman Test of 0.01 percent. However, the overall coefficient of determination shows high variability of close to one percent, while the model fitness is confirmed fit by F-statistic at 0.000 . The study suggested conclusion is the provision of sound risk management via collaborative-business growth model for optimally banks benefit in the region. Key-words:- Banks Profitability. Total Loan, Total Customer Deposit, Panel Data. Received: June 1, 2020. Revised: December 2, 2020. Accepted: December 15, 2020. Published: December $27,2020$.
\end{abstract}

\section{Introduction}

Prior existence of modern banking, activities relating to banks practices were predicated upon safe keeping in Babylon around 200BC. Store of gold, silver among other valuables were kept in the temple for safe custody [1]. As at the time, the fall out of the Royal mint ushered in the goldsmith era in United Kingdom, where more secured safekeeping was provided at a charge. Hitherto, commercial banking activities begun earnestly at Venice, Italy (Banca) in 1157, Germany, and France (Banqui) in 1800 and spread globally [1]. Thereafter, the scope of banking business broadened to include not only safe-custody and savings but loans, transfers, mobile/internet banking, advisory services, among others [2], [3]. Similarly, banking business had neared its full potentials about the time it entered into Africa in Europe and America. Obviously, colonization of most Africa countries was a factor. According to [2], [4], the establishment of Central Banks, which is a fall-out of political independence in most African counries, urshered in banking practices in the continent. For instance, the first established South African bank (Lombaard Bank) started in $23^{\text {rd }}$ April, 1793, until the establishement of South African Reserve Bank in 1921. While that of Ghana and Nigeria has their root in the year 1892/1894 under the Bank of British West Africa - African Banking Corporation from England prior the establishment of both Central Banks in 1957 and 1959 respectively. Without doubt, modern day sophistication has brought banking practices (especially commercial) to an unprecedented height of development involving stiff competition due to economic integration. Today, banks jostlefor new grounds beyond their territorial domain in order to increase profitability, deposit base, market value, and shareholders value among others [5], [6], [7], [8], [9] [10], [11], [12]. Literature attest to the fact that banks profitability is essential at greasing the wheel of economy progress [9] and,banks across Africa region have contributed their quota towards their respective economies in this regard. While banking reforms are common sin-qua-non in most emerging economies like that of Africa, its intermediation function is also not immuned to regional or global dictate.In order words, surviving altogether remains a continuous struggle in the spate of narrowing economy integration. Ironically, literature point to the fact that studies relating to the subject matter are numerous especially as it relates to policy adoption and practices however, that relating to comparative performance are scarcely available or better still, differs in terms of reference measurement [10], [13], [14]. As a result and without equivocation, the objective of the study seeks to examine commercial banks profitability vis-à-vis core mandate of deposit mobilization, granting of loans, in relation to total income generation. This shall be done with 
particular emphasis on South Africca, Ghana and Nigeria. Thus, the study is arranged in four sections. The literature review comes after the introduction. Following this, is the methodology and conclusion.

\section{Problem Formulation}

Banks are the engine of growth in an economy because of the sensitive position they occupy at making funds available to those who need them for investment purpose from those with surplus at a profit [6],[7], [15], [16]. In the midst of this intermediation, banks face challenges at making enough incometo keep them perpetually in business and to also satisfy their stakeholders, especially as the world becomes a global village. While banks must mobilize deposit at all times from the surplus units and lend same to deficit unit, it becomes imperative that they must achieve profitability in the process. Thus, banks income (interest/non-interest yield), are two vital components at generating profitability. In comparsionstudies had shown that banks (especially local) faces herculean task at making adequate and continuous income especially in the wake of global economic integration. This is so because foreign banks reneged to their mother bank in the event of crisis. For instance, [7] found that return on asset of foreign banks outperformed their local counterparts in Ghana. This is also the case of [6] and [8]in Pakistan. In Indian, [9] opined that profitability is key to productive activities among the banks in Germany. To [17], income diversification and bank size influences profitability in Nigeria. Similarly, [18] believes profitability is essential to banks growth in South Africa. [10] found a weak and mixed outcome of how performance impacted on growth of the two countries (Turkey and Romania )investigated [10]However, studies like [5], [6] observed somewhat different results between the performance of local banks and foreign banks in Pakistan. In fact, they found out that local banks performed profitably than their foreign counterparts. In spite of all, the depth of banks performance in presumed Africa emerging countries of South Africa, Ghana and Nigeria, remains a matter of concern especially in the wake of growing but uncertain global integration owing to the COVID-19 pandemic. This, thus, leaves room for a questionable proposition to which the study is concerned.

\subsection{Africa Banking System}

a. The South African [SA] Banking System

Banking system in Africa mirrored colonization of African countries. South Africa is not an exemption. Same features, for instance, presence of foreign banks, registrations and operational modalities featured in commercial banking practices in South Africa. What differs to a large extent is nomenclature as the case maybe. For example, commercial banking practices in South Africa has four divisions: commercial bank controlled and owned by the locals, commercial bank owned and controlled by the foreigners, commercial bank with international representative within the country and, mutually controlled commercial bank. [19]. Similarly, South Africa bank is considered one of the best in the continent. This is affirmed in the top twenty (20) ranking by World Economic Forum Global Competitiveness Survey (WEFGS) [18], [19], [21]. And, it is also ranked in third position by the same WEFGS from among the 148 countries [22]. A cursory glance at South Africa commercial banks performance is depicted below.

Fig. 1, South AfricanBanks(Comm.) Indicators

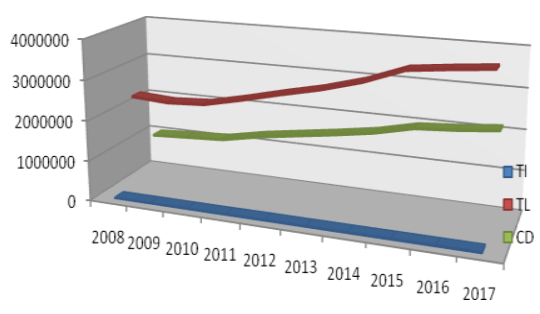

In South Africa, there is a reverse trend in manner in which banks activities occurred, unlike in other countries under review. Here, distribution of loans took the highest ranking as depicted by the graph and IMF 2018 report. This is also confirmed in[16]. By implication, total loans (TI) profile in South Africa commercial bank is the highest among the countries under review. However, there is a wide proportional difference in volume of total deposit and total income. When compared with other countries in review, South Africa has the least deposit liabilities. Though her deposit liabilities is 86.2 percent of total deposit according to [20], [23] this is however not in tandem with [16] study who examined a longer time series but 
assert that South Africa has the highest compared with Egypt and Nigeria. For total income, it shows that it is low over the period in review.

Generally, from twenty - two (22) registered banks, two (2) mutual banks, fifteen (15) and forty-four (44) branches of foreign local bank and representative banks respectively in 2003. Banks composition is South Africa now has seventeen (17) registered banks while the two mutual banks remain unchanged. There is a one-step dropdown of the international branches of foreign banks to fourteen (14). Foreign banks locally also dropped one place to forty-three (43) branches [20], [21]. Similarly, the Big - 5 commercial banks: ABSA Bank, Capitec Bank, First National Bank, NedBank and Standard Bank, holds a total of 5144 branches and 27,953 automated teller machines [22].

\section{b. The Ghanaian Banking System}

Banking practice in Ghana also depicts that of English invasion and eventual establishment of banking business. And unlike in South Africa, commercial banking practices in Ghana is simply universal banking practices where commercial banks are allowed to take on all financially related services [17], [8]. However, the country is home to foreign banks as of the case of all the countries under review. Presently Ghana has fifteen (15) foreign banks out of the total twenty seven (27) universal banks with a total of 904 branches [8]. A glance at the performance of Ghana commercial banks is depicted below.

\section{Fig. 2, Ghanaian BanKing Indicators}

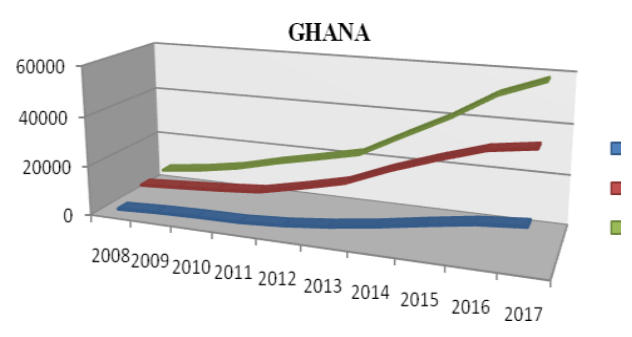

The Ghanaian commercial banks activities show a linearized trend of customer deposits (CD) for the period under review. Though, there was a steady increase between periods 2008 - 2013. This however increased significantly thereafter. Ghana commercial banks have the highest deposit among South Africa and Nigeria for the period in review. The country's commercial banks total loans (TL) is however lower in volume than that of South
Africa for same period. Further, total income (TI) indicate a moderately increase for the same period.

\section{c. The Nigerian Banking System}

The banking system in Nigeria comprises of privately and publicly owned banks. This case is not also different from the ones under review. The private are in the class of commercial banks comprising of local and foreign ownership; while that public owned are government established specialized banks. Like other countries in review, commercial banks number twenty five (25) with 5714 branches, 882 microfinance banks.The commercial performance is also depicted as below.

\section{Fig. 3, Ghanaian BanKing Indicators}

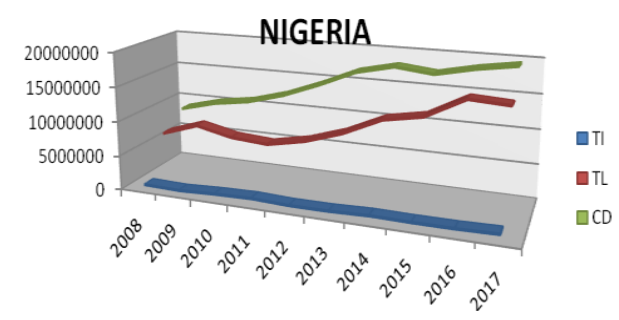

From the above, figure 3 represent the activities of commercial banks in Nigeria as presented by International Monetary Fund Financial Soundness Indicators. As shown, customer deposits (CD) indicator shows consistent rise in periods under review. The peak period was visible between 2013-2014, but a downward trend emerged in 2016 and rose again 2017. Also, the volume of total loans (TL) disbursed foot dragged in periods 2010, 2011, 2012 respectively. It latter showed a steady rise between 2014, 2015 and 2016 but dipped in 2017. This trend is compared with that of Ghana. However, profitability as described by total income (TI) maintained a rather low outcome.

\section{Problem Solution}

Empirical method adopted for the study is the Panel autoregressive distributed lag ARDL technique. Usually, where more than one country data are pooled at various times and crosschecked, the Panel data analysis becomes an appropriate technique [24], [25]. It serves the advantage of examining country specific (individually/jointly) in time $(\mathrm{t})$, years/period $(\mathrm{p})$ and number of years 
(y), as against other methodology. Normally, Panel data follows three empirical processes: i. Crosssection, ii. FE model and iii. The RE model.For Panel appropriateness, the Hausman test is often conducted to identify, jointly, country's specific charactersitics. Also, the study will perform the individual specific correlation coefficient relationship to ascertain individual country specif relationship with the variables in the study. Specifically, prior conducting the Panel ARD1, the descriptive analysis, the panel unit root test will also be conducted. As a rule, panel stationarity is tested and accepted on a common stationarity of either Levin, Lin \& Chu (LLC) [25], Breitung, LmPesaran\& Shin (LPS) [26], and Fischer-Type test (FT) [27] of Maddala\& Wu, Breitung Levine LLC [28] [29].In the study, Total income (TI) accrued from banks intermediation activities is proxied for banks profitability and serves as the dependent variable, Total loan (TL) and customer deposits (CD) are the independent variables across countries. Data for the study covers ten years period from 2008 to 2017 for three emerging economy: South Africa, Ghana and Nigeria. Data is sourced from World Bank arm of International Monetary Fund Financial Soundness indicator 2018.

\subsection{Model Specification}

In the general form of a regression model, the study mathetically derive;

$\mathrm{TI}=\mathrm{f}(\mathrm{CD}, \mathrm{TL})(1)$

Where:TI = total income (dependent variable) and $\mathrm{CD}=$ consumer deposits; $\mathrm{TL}=$ total loan (independent variable).

Thus, specifying ageneralizedPanel ARDL model in this process where we have, $\mathrm{N}=$ number of groups across sections (i.e. 3: Nigeria, Ghana and South Africa), in this case; $p, q . . q^{n}$ and $T=$ number of years (i.e. 10), isas follows;

$\Psi_{i t} \quad=\sum_{l=i}^{p} \beta_{i} \square i \Psi_{i, l-i}+\sum_{l=0}^{q} \beta_{i j} \square_{i, l-i}+\lambda i+\varepsilon_{1 t}$

Where: $\Psi_{i t}$ represent dependent variable, $\left(\square_{i, l-i}\right)$ is the $\mathrm{Kx} 1$ vector strictly $\mathrm{I}(0) / \mathrm{I}(1)$ only in unit root testing/cointegration factor, $\square l-i$, represents lag specification, $\beta_{i j}$ represents $\mathrm{kx} 1$ coefficients of vector, $\lambda i$ represents specific unit effects; $\mathrm{I}=$ $1, . . \mathrm{N} ; \mathrm{t}=1,2 \ldots, \mathrm{T} ; \mathrm{p}, \mathrm{q}$ represents lag selections while, $\varepsilon_{1 t}$ is the error term. Further, because series must undergo stationarity testing, which could lead to differencing and losing a lag, it is imperative that the Panel ARDL model is re-parameterized as follows;

$$
\begin{array}{r}
\Delta \Psi_{i t}=\Omega_{i}\left[\Psi_{i, l}-i,-\theta i \square_{i, l}\right]+\sum_{l=i}^{p-1} \phi_{i j} \Delta \Psi_{i_{l-i}} \\
+\sum_{j=0}^{q-1} \beta_{i j} \Delta \square_{i, l-i}+\lambda i+\varepsilon_{1 t}
\end{array}
$$

Where: ' $\Omega i=-\left(1-\beta_{i}\right)$, is the group-specific adjustment speed of coefficients where ' $\Omega i<0$. $\Theta i$, $\phi_{i j}$ and $\beta_{i j}=$ are the vectors of the long run and short run coefficient dynamics.

\subsubsection{Estimation Procedure}

Prior estimating the Panel, the study performed the descriptive test of the series to check for normality. Thereafter, the panel unit root test was also conducted using the LLC, Breitung, LPS and FT criterion. This was confirmed under HadriZstatfor most common unit root to be accepted for study prediction.

\subsubsection{Descriptive Stattistics}

The descriptives statistics used in the study are;

(a) The Skewness, which measure the asymmetry normality of the distribution. This is described under the assumptions that a; $0,+$ or - indicate symmetry, long right tail and long left tail respectively. The Skweness is represented thus;

$\mathrm{Skw}=\frac{\sum \mathbf{p}(\boldsymbol{\theta}-\lambda \rrbracket 3}{\tau \mathbf{3}}(4)$

(b) The Kurtosis: this measures the peakness or otherwise of series volatility with an assumption criteria of 3 . That is, when an output is $=3,<3$, or $>3$, then, the series is mesokurtic, flat, or peak respectively. Kurtosis is repreented thus;

$\mathrm{kts}=\frac{\sum \mathbf{p}(\boldsymbol{\theta}-\lambda \rrbracket \mathbf{4}}{\boldsymbol{\tau} \mathbf{4}}(5)$

(c) JarqueBera statistics conbine the composite result of skweness and kurtosis to give a combined coefficient. This is derived thus;

$\mathrm{JB}=p\left[\frac{(a b 1) 2}{6}+\frac{(b 2-3) 2}{24}\right](6)$

\subsubsection{Pooled Regression OLS}


The study used the cross-sectional analysis to kick-start its estimation process. The Pooled OLS panel allows for estimation in which the $\lambda_{\text {i are }}$ perpetual over time but with no specific $f_{\mathrm{t}}$ effect. By implication, this technique assumes homogeneity of all data sets in the panel without unique characteristics of $\lambda_{i}$ as such; treats all measurement with no universal effect over time.

\subsubsection{Fixed Effect (FE) Model}

The FE treats the heterogeneity observed in the Pooled OLS panel by fixing the unobserved characteristics. That is, it allows for individual cross-section intercept that is otherwise unobserved in the pooled regression but it is time invariant. This Ferdaous, (2016)regardsFixed Effect (FE) as the best fit, taking into account the treatment of unobserved heterogeneity among countries.

\subsubsection{Random Effects Model}

Panel analysis allow for a third verification of cross-section data inspection. This is done using the Random Effect (RE) model. Unlike, in FE which fixed all cross-section characteristics, the variance component model treats heterogeneity and time effect but the individual specific shock has no correlation relationship with the independent series in the study. Thus, the uncorrelated unobserved individuality country specific, variance component model allows for control using the generalized least square process.

\subsubsection{Hausman Test}

Conventionally, the three stages of analyzing cross-sectional series as treated above, leaves certain uncertainty in the acceptability of which of the model is most appropriate. For instance, the Pooled OLS do not distinguish between observations hence; variables are treated in homogeneity form. However, these lapses in Pooled OLS are then taking into consideration with Fixed Effect but with time invariant and vice versa with Random Effect (RE). To bridge this conflicting decision Hausman in 1978 proposed a $\mathrm{H}_{0}, \mathrm{H}_{\mathrm{a}}$ test of appropriateness as follows:

\section{$\mathrm{H}_{0}$ : $\mathrm{RE}$ model is the appropriate}

\section{$\mathrm{H}_{\mathrm{a}}$ : FE model is the appropriate}

By implication, the decision criterion is to reject null $\left(\mathrm{H}_{0}\right)$ if probability value falls below 0.05 percent level of significant, otherwise accept alternative $\left(\mathrm{H}_{\mathrm{a}}\right)$. [27], [28], [29]

\subsection{Results and Discussion}

\begin{tabular}{l|l|l|l}
\hline \multicolumn{1}{l}{ Table 1, Descriptive Result } & \\
\hline & TI & CD & TL \\
\hline Mean & 192716.8 & 5406304 & 4386365 \\
\hline Median & 21506.20 & 1506603 & 2859958 \\
\hline Maximum & 742512.8 & 19429168 & 15897520 \\
\hline Minimum & 1704.000 & 6949.000 & 5915.500 \\
\hline Std. Dev. & 267805.4 & 7033346 & 4812911 \\
\hline Skewness & 0.921787 & 0.951324 & 1.064443 \\
\hline Kurtosis & 2.088454 & 2.220868 & 3.112303 \\
\hline Jarque-Bera & & & \\
\hline Probability & 5.287100 & 5.283894 & 5.680959 \\
\hline & 0.071108 & 0.071222 & 0.058398 \\
\hline Observations & & & \\
\hline
\end{tabular}

As shown in table 1 above is the descriptive output of the study. Jusding by Skewness as explained in 3.1.2 (a), all the series are positive ( + ) hence, have a long right tail and are also symmetrical. Similarly, apart from total loan (TL) that is mesokurtic (i.e. $=3$ ), total income $(\mathrm{TI})$, and Consumer deposits (CD), are flat (i.e. $<3)$. Also, the JB shows the combined outcome of the series indicating positive coefficients of the series.

\begin{tabular}{|c|c|c|c|c|c|c|}
\hline \multicolumn{7}{|c|}{ Table 2, Panel Unit Root Test Result } \\
\hline & \multicolumn{4}{|c|}{ Total Income } & \multirow[t]{2}{*}{$\mathrm{CD}$} & \multirow[t]{2}{*}{ TL } \\
\hline Method & Statistic & Prob.** & C/sections & Obs & & \\
\hline \multicolumn{7}{|c|}{ Null: Unit root (assumes common unit root process) } \\
\hline LLC t* & \begin{tabular}{c|}
- \\
5.04250 \\
\end{tabular} & 0.0000 & 3 & 24 & 0.0071 & 0.0266 \\
\hline Breitung t-stat & $\begin{array}{c}- \\
0.76413 \\
\end{array}$ & 0.2224 & 3 & 21 & 0.3154 & 0.9669 \\
\hline \multicolumn{7}{|c|}{ Null: Unit root (assumes individual unit root process) } \\
\hline $\begin{array}{l}\text { LPS (Im, Pesaran and } \\
\text { Shin W-stat) }\end{array}$ & $\begin{array}{c}- \\
2.59342 \\
\end{array}$ & 0.0048 & 3 & 24 & 0.5321 & 0.5452 \\
\hline $\begin{array}{l}\text { ADF - Fisher Chi- } \\
\text { square }\end{array}$ & 28.2142 & 0.0001 & 3 & 24 & 0.5472 & 0.5702 \\
\hline PP - Fisher Chi-square & 17.6254 & 0.0072 & 3 & 27 & 0.7190 & 0.0684 \\
\hline Order of Integration & $\mathrm{I}(0)$ & & & & $\mathrm{I}(1)$ & $\mathrm{I}(1)$ \\
\hline \multicolumn{7}{|c|}{$\begin{array}{l}\text { ** Probabilities for Fisher tests are computed using an } \\
\text { asymptotic Chi }\end{array}$} \\
\hline $\begin{array}{l}\text {-square distribution } \\
\text { normality. }\end{array}$ & 1. All other & $r$ tests ass & sume asympt & & & \\
\hline
\end{tabular}

Having examined the descriptive statistics of the series to determine their normality characteristics, the study proceeded to test for the panel unit stationarity status. From table two, all assumed preconditions suggesting the presence of a unit 
root to either accept $H_{o}$ or reject $H_{a}$ or vice versa is indicated. However, the criteria is to accept or reject based on common charateristics. From the result, total income became stationary at order I(0) judging by LLC, Lm, Pesaran and Shin, Fisher outcome, as against Breitung. Similarly, these conditions were not satisfied in consumer deposits (CD) and total loan (TL) at order hence they were differenced. At first difference, only LLC satisfield stationarity condition at I(1) respectively hence, judgment was taken based on LLC condition.

\subsection{Panel ARDL Result}

Essentially, once the panel unit root status is determined, the next step is to perform Panel ARDL test based on the outcome of the unit root result. In essence, lag-length procedure is examined through lag-length selection criteria, which is essential to determine individual or joint country specifics. Specifically, Panel ARDL estimation process is performed when, after conducting the unit root, series are of order I(0) and order I(1) but not order I(2). That is, the series demonstrates different level of stationarity.In essence, the lag-length selection criteria is first determined, which will lead to ascertaining the short-run and long-run associations of the crosssections using the vector autoregressive regression (VAR) procedure. Below is the automatic laglength specification.

\begin{tabular}{|c|c|c|c|c|c|c|}
\hline \multicolumn{7}{|c|}{ Table 3, Automatic Lag Length Output } \\
\hline \begin{tabular}{l|l}
$\operatorname{Lag} \mid \mathrm{L}$ & \\
\end{tabular} & LogL & LR & FPE & AIC & $\mathrm{SC}$ & $\mathrm{HQ}$ \\
\hline 0 & 1087.430 & $\mathrm{NA}$ & $5.84 \mathrm{e}+35$ & 90.86919 & 91.01645 & 90.90826 \\
\hline 1 & 995.8711 & 152.5986 & $6.06 \mathrm{e}+32$ & 83.98926 & 84.57829 & 84.14553 \\
\hline 9 & 942.9633 & 74.95277* & $1.63 \mathrm{e}+31 *$ & $80.33027 *$ & $81.36107^{*}$ & $80.60375^{*}$ \\
\hline
\end{tabular}

Again, lag length selection criteria considers majority result as produced by various lag-length selection critieria in table 3 . This is to allow decision to be taken based on selctions adopted in the course of performing the autoregressive estimates. From the table, LR, FPE, AIC, SC and HQ system automatic lag selection (2) is common to the series. That is, the most appropriate laglength selection is given automatically as 2 indicated with the sign (*)and common to all selection criteria. By implication we have, LR($2)^{*}, \operatorname{FPE}(-2)^{*}, \mathrm{AIC}(-2)^{*}, \mathrm{SC}(-2)^{*}$ and $\mathrm{HQ}(-2)^{*}$, indicating that lag-2 is the optimal and appropriate.

\begin{tabular}{l|l|l|l|l}
\hline \multicolumn{1}{l}{ Table 4, Panel ARDL Result } \\
\hline $\begin{array}{l}\text { Dependent Variable : Total Income } \\
\begin{array}{l}\text { Independent } \\
\text { Variable }\end{array}\end{array}$ & $\begin{array}{l}\text { Model I: } \\
\text { Pooled } \\
\text { Regression }\end{array}$ & $\begin{array}{l}\text { Model } \\
\text { II: FE }\end{array}$ & $\begin{array}{l}\text { Model } \\
\text { III: RE }\end{array}$ \\
\hline $\begin{array}{l}\text { Total Loan } \\
\text { (TL) }\end{array}$ & Prob & 0.0714 & 0.8204 & 0.0724 \\
\hline & Coefficient & -0.0169 & -0.0025 & -0.0169 \\
\hline & & & & \\
\hline $\begin{array}{l}\text { Total } \\
\text { Deposits }\end{array}$ & Prob & 0.000 & 0.0280 & 0.000 \\
\hline & Coefficient & 0.048 & 0.0245 & 0.0480 \\
\hline & R-Squared & 0.94 & 0.95 & 0.94 \\
\hline & $\begin{array}{l}\text { Hausman } \\
\text { Test }\end{array}$ & & & 0.01 \\
\hline
\end{tabular}

\subsubsection{Pooled Regression (Model I)}

The pooled regression shown in the table indicate that total loan (TL) is statistically insignificant having fall above the 0.05 percent level of significant at 0.07 . By this result, it means the hypothesis of no significant relationship between total income (TI) and total loan is true. Conversely, total deposits (TD) is statistically significant at 0.000 percent hence, the null hypothesis of no significant relationship between commercial bank's total income (TI) and total deposit (TD) is false. However, there is a caveat to the acceptability potential of pooled panel outcome because it does not take into consideration the individuality of observations in the model that is, it assumes homogeneity of character and universal effects for all countries in the model. As such, other models of FE and RE are considered.

\subsubsection{Fixed Effect Model (Model II)}

Since the pooled OLS do not take into account individual cross-sections specific characteristics leading to missing unobserved country specific, it then means that all observation are the same. As a consequence, the Fixed Effect (FE) provides possible option. As a rule, the FE treats the unobserved characteristics and accounts for individual variable characteristics, universal effects with unique difference in intercept but is time invariant. Also the error term vary nonstochastically over each cross-sections and period [23]. Again, total loan (TL) in FE model shows insignificant relationship hence, the null is true. Whereas, total deposit (TD) is significant hence, the null is false. Because FE is fixed over time and correlated with the independent variables the RE suffices.

\subsubsection{Random Effect Model (Model III)}

The Random Effect is the third method in the process of panel analysis. It takes into consideration heterogeneity, time invariant but the 
individual effect is uncorrelated. It allows for the control of unobserved heterogeneity through the general least-square method (GLS) where error terms of observations are randomly distributed [23], [24]. Again, total loan shows insignificant relationship with the total income; while total deposit is statistically significant at 0.000 percent given 0.05 level of significant.

\subsubsection{Hausman Test}

To determine the appropriateness of model to adopt for prediction and for acceptability purpose, the Hausman test is applied. Accordingly, if $\mathrm{H}_{0}$ is significant, then FE is appropriate otherwise, RE is appropriate. Based on the result, FE model is appropriate for the study. The result of this study also corroborate [23]. Thus, total loan is statistically insignificant to explain total income in the study. This is indicated by prob 0.820 , which is higher than the 0.05 percent level of significant hence, it is insignificant. However, worthy of note is the negative coefficient at -0.002 which falls in line with economic principles and leaves us with a caution. Expectedly, the higher the volume of total loan disbursed the higher banks returns in expected income. Conversely, since total deposit is statistically significant at 0.02 to explain total income, on the whole,FE R-squared result which measures the overall degree of responsiveness to a one percent change between dependent and independent variable is explained by 0.94 percent of variation, indicating high variability between the variables. By implication, the result of the study show that, collectively, Nigeria, Ghana and South Africatotal banks performance is explained by total customers' deposit rather than total loan.

\subsubsection{Individual Specific Correlation Result}

\begin{tabular}{l|r|r|r|r}
\hline \multicolumn{1}{l}{ Table 5, Nigeria } \\
\hline Series & Coefficient & Std. Error & \multicolumn{1}{c}{ t-Stat } & Sig * \\
\hline COINTEQ01 & -2.292211 & 0.093082 & -24.62567 & 0.0001 \\
\hline $\mathrm{D}(\mathrm{TI}(-1))$ & 0.518216 & 0.044915 & 11.53775 & 0.0014 \\
\hline $\mathrm{D}(\mathrm{CD})$ & -0.061502 & 0.001510 & -40.72178 & 0.0000 \\
\hline $\mathrm{D}(\mathrm{CD}(-1))$ & -0.111463 & 0.000733 & -152.1033 & 0.0000 \\
\hline $\mathrm{D}(\mathrm{TL})$ & -0.074670 & 0.000144 & -517.2181 & 0.0000 \\
\hline $\mathrm{D}(\mathrm{TL}(-1))$ & -0.039690 & 0.000632 & -62.81194 & 0.0000 \\
\hline $\mathrm{C}$ & 81844.25 & $4.25 \mathrm{E}+09$ & $1.93 \mathrm{E}-05$ & 1.0000 \\
\hline
\end{tabular}

The individual country specific relationship of the dependent and independent variables were also examined. The essence is to determine the individual country's commercial bank performance in terms of profitability. Thus, in Table 5, the result showed that Nigeria commercil bank customer deposit - $\mathrm{D}(\mathrm{CD}(-1))$ is significant at a sig* $=0.0000$. This significant outcome for the country suggest possible favourable policy in the following regard. First, there is a possibility of savings incentive, which laid credence to savings habit within the country. Secondly, is also the possibility of banks ability to create additional money in the system due to high deposit mobilization rate. Or, simply the financial inclusion drive policy on the side of the monetary authorities, among others. Similarly, the result is also similar in the relationship between total loan and total income for the country. The result showed that $\mathrm{D}(\mathrm{TL}(-1))$ is statistically significant at sig* $=0.000$. Again, what the result implies stem from the fact that the banks intermediation function is also optimal to explain its total income. By extention, banks in the country are sufficiently liquid as well as effectively performing their intermediation role.

\begin{tabular}{l|r|r|r|r}
\hline \multicolumn{1}{l}{ Table 6, Ghana } \\
\hline Series & Coefficient & S.E & \multicolumn{1}{c}{ t-Stat } & Sig. * \\
\hline COINTEQ01 & -0.152672 & 0.005486 & -27.82740 & 0.0001 \\
\hline $\mathrm{D}(\mathrm{TI}(-1))$ & 0.733732 & 0.111567 & 6.576572 & 0.0072 \\
\hline $\mathrm{D}(\mathrm{CD})$ & -0.121160 & 0.002880 & -42.07100 & 0.0000 \\
\hline $\mathrm{D}(\mathrm{CD}(-1))$ & 0.094529 & 0.004766 & 19.83260 & 0.0003 \\
\hline $\mathrm{D}(\mathrm{TL})$ & 0.345526 & 0.003024 & 114.2730 & 0.0000 \\
\hline $\mathrm{D}(\mathrm{TL}(-1))$ & 0.069957 & 0.013151 & 5.319450 & 0.0130 \\
\hline $\mathrm{C}$ & -72.75792 & 10966.68 & -0.006634 & 0.9951 \\
\hline & & & &
\end{tabular}

In Ghana, commercial banks performance is also visible judging by the result. From the table, the customer deposit $\mathrm{D}(\mathrm{CD}(-1))$ indicate a statistically significant relationshipagainst total income at a sig* 0.0003 . This means that, the null hypothesis is rejected also for Ghana. Possible reasons responsible for this outcome may not be completely different from that of the Nigerian context. More so, Ghana's geographical location, which falls within the same Western - Africa region as in the case of Nigeria, provides an avenue for common shared financial charactersitics which may be responsible for this outcome.As a result, possible saving induced incentives, government policy and the monetary authority drive towards financial inclusion are seen as driver to these significant outcome. However, unlike in the case of Nigeria, total loan D(TL(-1) in Ghana is also positive and statiscally significant. But the sig* 0.013 indicate a moderately 
significance outcome unlike that of Nigeria. What this mean is that, commercial bank intermediation function in the Ghanian settings comes with minor moderation either propelled as a result of policy implication or as a result of banks deliberate act.

Table 7, South Africa

\begin{tabular}{c|r|r|r|r}
\hline Series & Coefficient & \multicolumn{1}{c|}{ S.E } & \multicolumn{1}{c|}{ t-Stat } & Sig. * \\
\hline \hline & & & & \\
\hline COINTEQ01 & -0.797542 & $1.38 \mathrm{E}-08$ & -57590530 & 0.0000 \\
\hline $\mathrm{D}(\mathrm{TI}(-1))$ & 0.193573 & $1.53 \mathrm{E}-09$ & $1.26 \mathrm{E}+08$ & 0.0000 \\
\hline $\mathrm{D}(\mathrm{CD})$ & 0.017648 & $5.51 \mathrm{E}-11$ & $3.20 \mathrm{E}+08$ & 0.0000 \\
\hline $\mathrm{D}(\mathrm{CD}(-1))$ & 0.095300 & $5.04 \mathrm{E}-11$ & $1.89 \mathrm{E}+09$ & 0.0000 \\
\hline $\mathrm{D}(\mathrm{TL})$ & 0.001743 & $7.56 \mathrm{E}-12$ & $2.31 \mathrm{E}+08$ & 0.0000 \\
\hline $\mathrm{D}(\mathrm{TL}(-1))$ & -0.052644 & $9.27 \mathrm{E}-12$ & $-5.68 \mathrm{E}+09$ & 0.0000 \\
\hline $\mathrm{C}$ & -946.8052 & 2.666373 & -355.0911 & 0.0000 \\
\hline
\end{tabular}

Similarly, the result of the individual country's commercial bank performance showed that South African's commercial banks have performed profitably in their operations for the period in review. A cursory glance at the result indicate that commercial banks deposit mobilization drive in South Africa, as proxied by customer deposit $\mathrm{D}(\mathrm{CD}(-1))$, is positive and statistically significant. The result showed a sig* 0.0000 hence, the null hypothesis of no relationship between customer deposit and total income of the banks is rejected. In essence, the result equally suggest that, saving incentives, government policy drive and the apex regulatory framework provides avenue that have resulted into the positive and significant outcome been witnessed as well. Also, total loan as mirrored by $\mathrm{D}(\mathrm{TL}(-1))$ is positive and statistically signfifant. The sig* 0.000 , shows that the null hypothesis is not accepted but the alternatve. Again, this outcome presupposes that South African commercial banks equally play significant role in financial intermediation as evident form the result.

Overall and from the stand-alone view-point, the results for the countries - Nigeria, Ghana and South Africa understudied, shows, to a large extent, that commercial banks within the region and indeed Africa, are highly profitable. This outcome is in-line with [8],[9], study.

\subsubsection{Discussion of Findings}

Having examined the individidual and jointly comparison analysis of banks performance in selected countries in Africa: Nigeria, Ghana and South Africa, findings suggest that banks intermediation role in their respective countries is optimally, especially judging from the time trajectory adopted for the study. It also shows that individually, their performance activities learn credence to their profitability. However, jointly, findings suggest that comparative benefits that is accrueable to international banking practice advantages are not maximized. This is judging from the panel result, which shows that total loan is inadequate in predicting performance hence, a concern for players at the international arena.

\section{Conclusions}

Attempt at analyzing commercial banks profitability informed this study. For sound and robust reviews of end report, the study took at comparing commercial banks across countries in Africa with emphasis on Nigeria, Ghana and South Africa owing to presumed position they occupy in the continent. To achieve its aims and from data provided by World Bank Group - International Monetary Funds, the study mirrored commercial banks profitability with total income (TI) hence, the dependent variable. The independent variables were proxied by total loan (TL) and customer deposits (CD). The period used covers a ten (10) year period across cross -sections. Results from the Panel ARDL regression find Fixed Effect model appropriate. However, total loan to total income was statistically insignificant but with a caveat as presented by negatively signed correlation. This is because the outcome comform with interest rate theory. That is, it is inversely related, and that the lower the interest rate, the higher the propensity to borrow and, this, conform with economic theory.In essence, the outcome Customer deposit (CD) to total loan (TL) was statistically significant. Similarly, the coefficient of determination as measured by R-squared indicates high variability of variables used. The fitness of the model is however confirmed by prob(F-statistic) at 0.000 . The study conclude on the joint strength of the study as reported by the Panel ARDL and Hadriresult that banks need to seize international arena advantages in flexing their intermediation role.

\section{Reference:}

[1]Okereke EJ, Sanni TA, Anyanwu GA,Ogunbiyi SS,Money and the Nigerian Financial System,

Jeso International, Owerri, 2009.

[2] Okunlola FA, Alatise MA, OgunniyiOR,

Adejumo MO, Financial inclusion for sustainable economy: Empirical evidence from Nigeria, WSEAS Transactions on Business and Economics, Vol.17, 2020, pp. 205-214

[3] Babajide AA, Adedoyin L,UmorenG,Isibor

AA, Financial inclusion in Nigeria: Prospect, issues and challenges. Proceedings of the 33rd International Business Information Management Association Conference, IBIMA 2019: Education Excellence and Innovation Management through Vision 2020,

[4] Afolabi L,Monetary Economics, Perry Barr Ltd Lagos, 1998. 
[5] San TO, Theng LY, Heng T.B. A comparison onEfficiency of Domestic and foreignBanks in

Malaysia: A DEA Approach, Business

Management Dynamics, Vol.1, No. 4, 2011, pp.

33-49.

[6] Adeel H. Domestic vs foreign: A comparison of

financial performance of Domestic and Foreign

Banks in Pakistan, Thesis: University of Agder,

Pakistan, 2012.

[7]Azam M, Siddiqui S, Domestic and Foreign banks' Profitability: Differences and their determinants. International Journal of Economics and Financial Issues, Vol. 2, No. 1, 2012, pp. 33-40

[8] Alnaa SE, Adongo J, Juabin M, Comparative analysis of profitability of local and foreign banks in Ghana, Asian Economic and Financial Review, Vol. 6, No. 5, 2016, pp. 238-246

[9] Satapaty B, Bhubaneswar G, Analysis of Profitability of Banks: Comparative study of domestic and foreign banks in India.

International Journal of Research and

Development-Management Review, Vol. 5, No. 4, 2016

[10] Turkes M, Constantinescu L, ToporD, Comparative analysis of banking performance of Commercial banks Groups. Case study: Turkey Vs. Romania. Bulletin of Taras Schevchenko National University of Kyiv, Economics, Vol. 3, No. 198, 2018, pp. 87-94 [11]Isibor A, Olokoyo F, Maria A,Osuma GO, Chisom N, Exchange rate management and sectoral output performance, International Journal of Supply Chain Management, Vol.7 No.5, 2018, pp. 129-134

[12]Isibor A, Ojo JAT, IkpefanOA Does financial deregulation spur economic development in Nigeria? Peer-Reviewed Proceedings of the International Business Information Management Association Conference ( $31^{\text {st }}$ IBIMA) held on 25 - 26 April 2018, Milan, Italy.

[13] Ekpo N.B, Mbobo M.E, Asset structure and Profitability of Microfinance Banks: Evidence from AkwaIbom State, Nigeria, International Journal of Finance and Management in Practice, Vol. 4, No. 1, 2016 [14] Muda MA, Shaharuddin A, EmbayaA, Comparative analysis of profitability determinants of domestic and foreign Islamic banks in Malaysia,International Journal of Economics and Financial Issues, Vol. 3, No. 3, 2013, pp. 559-569.

[15]Kouser R, Saba I, Gauging the financial performance of banking sector using camel model: Comparison of conventional, mixed and pure Islamic banks in Pakistan,

International Research Journal of Finance and Economics, Vol. 82, 2012, pp. 67-88.

[16] Valbona C, Manuela M, Artur R, Ilda K, The Need for Improvement of External Audit Reports of Banks WSEAS Transactions on Environment and Development, Vol. 16, 2020, pp. 539-547

[17] Yuri M, Anna K, Behavior of Drop-Tail QueueManagement Algorithms under High Packet
Loss, WSEAS Transactions on Systems and Control, Vol. 14, 2019, pp. 90-96

[18]RonaldR,Financial institutions, marketand structure linkages with economicperformance in selected African countries: Time Series EvidencePh.DDissertation, 2018, University of Stellenbosch, South Africa, Retrieved from https://scholars.sun.ac.za [19]Owusu MK, Determinants of performance of commercial Banks in Ghana, Master's thesis, 2014, Kwame Nkrumah University of Science and Technology, Ghana.

[20] Kumbirai M, Webb R, A Financial ratio analysis of Commercial Bank performance in South Africa, African Review of Economics and Finance, Vol. 2, No. 1, 2010.

[21]Godza P, Financial structure and economic growth nexus: Comparisons of Banks,

Financial Market and Economic Growth in South Africa, Master's thesis, 2016, University of Fort Hare, East of London, South Africa. [22] The Banking Association South Africa, (TBASA), World Economic Forum on Global Competitiveness Survey 2014.

[23] South African Reserve Bank (SARB), FinancialReport, 2011.

[24]Ferdaous J, Impact of Remittances and FDI on Economic Growth: A Panel data analysis. Journal of Business Studies Quarterly, Vool. 8, No. 2, 2016.

[25] Misman FN, Introduction to Panel Data Analysis using Eviews. Panel Data Workshop, 23 \& 24 May, 2017, Finance Department, UiTM, Johor.

[26] Salvatore D, Reagle D, Statistics and Econometrics, McGraw Hill, 2011.

[27] Pesaran MH, Shin Y, An Autoregressive Distributed lag modeling approach to cointegration analysis. Econometrics and Economic Theory in the $20^{\text {th }}$ century: The Ragnar Frisch Centennial Symposium, Cambridge University Press, 1999

[28]Pesaran MH, Shin Y, Smith RJ, Bound testing approaches to the analysis of level relationships, Journal of Applied Econometrics, Vol.16, 2001, pp. 289-326.

[29] Nkoro E, Uko AK, Autoregressive Distributed Lag (ARDL) cointegrationtechnique:

Application and interpretation, Journal of Statistical and Econometrics Methods, Vol.5, No.4, 2016, pp. 63-91.

\section{Authors' Contribution}

Babajide Abiola was responsible for proof-reading and editing the work.

Isibor Areghan was responsible for supervising the study and references.

Adedoyin Lawal carried out the introduction and literature review.

Okafor Tochukwu gathered the data, defined the methodology.

Okunlola Abiodun analyzed the data and did recommendations and conclusion.

\section{Creative Commons Attribution License 4.0} (Attribution 4.0 International, CC BY 4.0)

This article is published under the terms of the Creative Commons Attribution License 4.0

https://creativecommons.org/licenses/by/4.0/deed.en_US 